\title{
The impact of foreign capital shifts on economic activities and asset prices: a threshold VAR approach
}

\author{
Boubekeur Baba \\ Department of Business administration, Anadolu Üniversitesi, \\ Eskisehir, Turkey, and \\ Güven Sevil \\ Open Education Faculty, Anadolu Üniversitesi, Eskisehir, Turkey
}

\begin{abstract}
Purpose - The purpose of this paper is to investigate the impact of foreign capital shifts on economic activities and asset prices in South Korea.

Design/methodology/approach - The authors in this paper apply the Bayesian threshold vector autoregressive (TVAR) model to estimate the regimes of large and low inflows of foreign capital. Then, structural impulse-response analysis is used to check whether the responses of the variables differ across the estimated regimes. The model is estimated using quarterly data of foreign capital inflows, gross domestic product (GDP), consumer price index, credit to the private non-financial sector, real effective exchange rate (REER), stock returns and house prices.
\end{abstract}

Findings - The main findings suggest that large inflows of gross foreign capital, foreign direct investments (FDI) and foreign portfolio investments (FPI) are ineffective to boost economic growth, but large inflows of other foreign investments (OFIs) significantly contribute to GDP. The decreases in the foreign capital inflows are associated with larger depreciation of REER. The large inflows of gross foreign capital, FDI and OFIs are associated with further expansion of credit supply to private nonfinancial sectors.

Research limitations/implications - The policy implications of foreign capital inflows are of particular importance to all the emerging markets alike. However, the empirical analysis is limited to the case of South Korea due to various reasons. The experience with international capital inflows among emerging markets is heterogeneous. Therefore, it would be better to take each case of emerging market individually. In addition, TVAR analysis requires a long data sample, which unfortunately is not available for most of the emerging markets.

Originality/value - The foreign capital inflows are shown to be procyclical and notoriously volatile in many studies. Nevertheless, this topic has commonly been studied using linear VAR models, which do not

(C) Boubekeur Baba and Güven Sevil. Published in Asian Journal of Economics and Banking. Published by Emerald Publishing Limited. This article is published under the Creative Commons Attribution (CC BY 4.0) licence. Anyone may reproduce, distribute, translate and create derivative works of this article (for both commercial and non-commercial purposes), subject to full attribution to the original publication and authors. The full terms of this licence may be seen at http:// creativecommons.org/licences/by/4.0/legalcode

JEL classification - F21, F32, F36, F41, G12

The authors truly appreciate the helpful comments from the anonymous reviewers.

Funding: This study did not receive any kind of financial support from any organization.

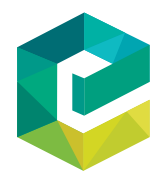

Asian Journal of Economics and Banking 
AJEB 4,3

properly deal with the cyclical characteristics of foreign capital inflows. This study attempts to resolve these methodological limitations by examining a non-linear VAR model that is capable of capturing the structural breaks associated with the cyclical behaviors of foreign capital inflows.

Keywords Foreign capital inflows, Regime shifts, Economic growth, Credit expansion, Asset prices, Bayesian threshold VAR, South Korea

Paper type Research paper

\section{Introduction}

For many emerging markets, the ability to draw a large amount of international capital has been considered potentially beneficial to the economy, particularly in the early 1990s. Exploiting the foreign resources of capital helped these countries to overcome the low levels of capital per worker, subsequently leading to booming outputs and sustainable long-term growths. Despite these benefits, large inflows of foreign capital have occasionally been associated with undesirable consequences of exchange rate appreciation and financial and asset price cycles. Some types of foreign capital inflows, principally short-term investments, have been notoriously volatile giving rise to frequent boom-bust cycles in the recipient economy. These cycles typically start with credit expansion, increases in asset prices and exchange rate appreciations. However, these realized gains were most likely to be abruptly obliterated by a sudden reverse of foreign capital inflows. In a broader context, history also shows that many of the boom-bust cycles have been synchronous with the patterns of surges and sudden stops in international capital flows.

Over the past four decades, foreign capital flows experienced several large waves sweeping through many emerging markets. The first wave coincides with the capital control relaxing policies adopted by emerging markets by the end of the 1980s. However, it came to an abrupt end with the break-out of the Asian currency crisis in 1997. The second wave of large foreign capital inflows was observed by the beginning of 2003 , the end of this wave was marked by the wake of the global financial crisis in 2008. During this period, capital inflows to emerging Asian countries reached $\$ 200 \mathrm{bn}$ in 2005 as documented by Kim and Yang (2011). Meanwhile, most of the Asian stock indexes significantly pushed up accumulating a total of 50\% increase by the end of 2007 . Surprisingly, though net capital flows, particularly to emerging Asia, rebounded at a record pace following the global financial crisis. The last resurgence of international capital mobility was soon interrupted by the intensifying European sovereign debt crisis in 2011. Besides the appreciation of asset prices and exchange rates, credit expansion has been widely perceived to be strongly associated with large waves of foreign capital inflows. Some authors have even argued that credit expansion and inflows of foreign capital are closely interconnected as they tend to reinforce one another (Aliber and Kindleberger, 2015). Nevertheless, and perhaps, surprisingly, the link between capital inflows and credit expansion seems to be not factually established in much of the literature in this area. This lack of consensus, however, is not exclusive to the studies on the link of credit expansion and large inflows of foreign capital. Other strands of literature have often shown discordant empirical evidence on the impact of foreign capital inflows on asset prices and economic growth as well.

The inconclusiveness of evidence might be sensible considering the fact that the effectiveness of foreign capital inflows is conditional on the economic characteristics of the recipient country. Alternately, the strong presence of surges and reversals in foreign inflows of capital may lead to biased estimation of the aggregate impact. In other words, indiscriminately dealing with these irregular periodic patterns could lead to overlooking of the different impacts generated by the cycles of foreign capital inflows. Consequently, the outcomes could be conflating the impact of different regimes of capital inflows. Additionally, the outcomes could 
differ across countries depending on the country-specific volatility of foreign capital inflows. To solve this problem, this study uses the two-regime Bayesian threshold vector autoregressive (TVAR) model developed by Alessandri and Mumtaz (2017). The empirical estimation of the model is carried out using South Korean data that consists of capital inflows, macroeconomic variables and asset prices. The Bayesian TVAR allows the impact of foreign capital inflows to vary with an internally estimated threshold. This further means that the size and the propagation mechanisms of shocks are, to some extent, inherently adjustable to the surges and reversal dynamics in the capital inflows.

Studying the dynamics and mobility of international capital flows has been an active field of research (Calvo, 1998; Reinhart and Reinhart, 2009; Forbes and Warnock, 2012; Cardarelli et al., 2010; Ghosh et al., 2014). However, the causal links of these dynamics with asset prices and exchange rates have mostly been anecdotally described and built upon the temporal coincidence of these events with the changes in the price behaviors of these assets. Many of the empirical works have instead relied on linear VAR models that do not properly deal with the cyclical characteristics of international capital inflows. On the other hand, the literature seems to be fond of the connectedness of international capital cycles with lending booms and banking crises. This study attempts to resolve these methodological limitations by examining a nonlinear VAR model that is capable of capturing the structural breaks and regime shifts associated with the cyclical behaviors of capital inflows. Although the threshold methodology used in this study does not closely follow the criteria set by the literature on the cyclical episodes of international capital flows [1], it manages to separately tackle the impact of these behaviors and incorporates it with other observed periodical ups and downs.

\section{Related literature}

This study is linked to several strands of international finance literature. In this section, we briefly highlight the recent empirical outcomes from this literature. It is conventionally perceived that capital inflows are supposed to yield several benefits for the recipient country. Henry (2007), DeLong (2004), Rodrik and Subramanian (2009) suggest that higher investment as a share of gross domestic product (GDP) should lead to higher growth, at least temporarily. This perception, however, is still highly controversial until today. Studies such as Javorcik (2004) and Li and Liu (2005) report a strong nexus between foreign direct investments (FDI) inflows and economic growth. Choong et al. (2010) and Aizenman et al. (2013) examine the impact of different forms of private capital flows on economic growth. These studies find that economic growth is positively related to FDI inflows, but other forms of foreign capital, particularly foreign debt and portfolio investment, are harmful to economic growth. Kose et al. (2009), on the other hand, find evidence that even portfolio equity inflows can improve the total factor productivity growth. Based on a sample of 24 emerging countries, Beckmann and Czudaj (2017) also find that both gross and net capital flows display a positive impact on economic growth except in South Korea. Contrary to these findings, a group of other studies reports no impact of FDI on economic growth. Agosin and Machado (2005) state that FDI at best left domestic investment unchanged in a panel of 36 developing countries. Carkoviç and Levine (2005) similarly find no robust boost of economic growth from FDI. Conforming to these studies, the empirical tests carried out by Carbonell and Werner (2018) for Spain also yielded no evidence that FDI can stimulate economic growth.

In a closely related strand of literature, the researchers have long debated the role of foreign capital inflows as a driver of credit growth. The empirical findings from Hernandez and Landerretche (1999) are supportive of the perception that capital inflows tend to fuel credit growth. Magud et al. (2014) find that bank credit is larger during periods of large capital inflows. Using a sample of 33 countries, Igan and Tan (2017) show that capital inflows boost credit growth and increase the likelihood of credit booms in both household 
AJEB

4,3

and corporate sectors. Baskaya et al. (2017) examined the role of the international credit channel in Turkey and found evidence that banks increase credit supply when capital inflows are higher. However, empirical evidence from another set of papers opposed these findings. Sachs et al. (1996) found no association between lending booms and large capital inflows during the crises in the 1990s. Similar findings are also reported by Sa (2006), who finds no causal relationship between capital inflows and credit booms in a sample of 27 emerging countries. Calderon and Serven (2013) reported mixed evidence on the association between large capital inflows, asset price booms and lending booms.

This paper is also related to the literature on the impact of foreign capital inflows on asset prices. The inconclusiveness of empirical evidence exists in this literature as well. Caballero and Krishnamurthy (2006) argue that the shortcomings of emerging markets such as the shortage of value stores and financial repression together with capital inflows can lead to a bubble in asset prices. However, Ventura (2012) argues that asset bubbles act as a substitute for international capital flows. Ventura (2012) further suggests that the appreciation of asset prices can be observed even in the absence of foreign capital inflows. Empirically, Jansen (2003) finds the private capital inflows to be associated with higher asset prices, modest inflation and modest real exchange rate appreciation in Thailand. Kim and Yang (2009) studied the impact of capital inflows on asset prices in South Korea, their findings showed that the capital inflows have indeed contributed to the increase of stock prices, but it had a limited effect on exchange rate appreciation in South Korea. In another study, on a panel of emerging Asian countries, Kim and Yang (2011) find that capital inflow shocks explain a relatively small part of asset price fluctuations. Brana et al. (2012) find evidence of spillover effects of excess liquidity at a global level on output and price levels in emerging countries, but this impact is found to be less clear for real estate, commodity and share prices.

\section{Methodology and model specification}

\subsection{Methodology}

3.1.1 Bayesian threshold vector autoregressive model. Let us assume we have a linear VAR (p) model described as follows:

$$
Y_{t}=c_{1}+\sum_{j=1}^{P} B_{j} Y_{t-j}+\Omega^{1 / 2} e_{t}, \quad e_{t} \sim N(0.1)
$$

Following Alessandri and Mumtaz (2017) and their notation, the non-linear Bayesian TVAR can be estimated by rewriting the equation (1) as follows:

$$
Y_{t}=\left[c_{1}+\sum_{j=1}^{P} B_{1} Y_{t-j}+\Omega_{1 t}^{1 / 2} e_{t}\right]\left(1-\tilde{S}_{t}\right)+\left[c_{2}+\sum_{j=1}^{P} B_{2} Y_{2 t-1}+\Omega_{2 t}^{1 / 2} e_{t}\right] \tilde{S}_{t}
$$

Where $e_{i t} \sim N(0,1), \tilde{S}_{t}=1 \Longleftrightarrow I N F_{t-d} \leq I N F^{*}$ for $t=1, \ldots, T$.

$Y_{t}=(N \times 1)$ is the vector that contains the endogenous variables and $\left\{\mathrm{c}, B_{s, j}, \Omega_{i t}\right\}$ are the parameters for the two regimes $i=1,2$. The lag length is set at 1 as indicated by the information criteria.

The regimes are set by the shift in foreign capital inflows, the shift is determined by the thresholds $I N F^{*}$, which indicates large and low capital flows $I N F_{t-d}$. The thresholds, in turn, are determined by the delay parameter $d$, which is the number of lags for the threshold 
variable $I N F_{t-d}$. The maximum delay is set to range between 1 and 10 and its optimal value is internally estimated by the threshold autoregressive model. Setting the delay parameter to range between 1 and 10 enables the algorithm to capture the flow declines and regime shifts that are not exclusively linked to the period of crises.

The prior used is a natural conjugate prior as described in Banbura et al. (2010), for both regimes it uses the following dummy observations:

$$
Y_{D, 1}=\left(\begin{array}{c}
\frac{\operatorname{diag}\left(\gamma_{1} \sigma_{1} \ldots \gamma_{N} \sigma_{N}\right)}{\tau} \\
0_{N x(P-1) x N} \\
\ldots \ldots \ldots \ldots \\
\operatorname{diag}\left(\sigma_{1} \sigma_{N}\right) \\
\ldots \ldots \ldots \ldots \\
0_{1 x N}
\end{array}\right), \text { and } X_{D, 1}=\left(\begin{array}{cc}
\frac{J_{p} \otimes \varnothing \operatorname{diag}\left(\sigma_{1} \ldots \sigma_{N}\right)}{t} & 0_{N P x 1} \\
0_{N x N P} & 0_{N x 1} \\
\ldots & \ldots \\
0_{1 x N} & c
\end{array}\right)
$$

Impact of foreign capital shifts

where $\sigma_{1} \sigma_{N}$ represents standard deviations of the error term of an AR model estimated using each endogenous variable, $\gamma_{1}$ to $\gamma_{N}$ denotes the prior mean for the coefficients on the first lag, $\tau$ is the tightness of the prior on the VAR coefficients and $c$ is the tightness of the prior on the constant terms. The hyperparameters $\tau$ and $c$ have been set at values 0.1 and 1 , respectively. The prior on the sum of the lagged dependent variables are also introduced by adding the following dummy observations:

$$
Y_{D, 2}=\frac{\operatorname{diag}\left(\gamma_{1} \mu_{1} \ldots \gamma_{N} \mu_{N}\right)}{\lambda} \text { and } X_{D, 2}=\frac{1_{1 x P} \otimes \varnothing \operatorname{diag}\left(\gamma_{1} \mu_{1} \ldots \gamma_{N} \mu_{N}\right)}{\lambda}
$$

where $\mu_{i}$ denotes the sample means of the endogenous variables. The tightness of this sum of coefficients prior is set as $\lambda=10 \tau$.

Given the natural conjugate prior, the conditional posterior distributions of the VAR parameters $B$ and $\Omega$ take a simple form and are defined as:

$$
\begin{gathered}
G(B / \Omega) \sim N\left(B^{*}, \quad \Omega \otimes\left(X^{*^{\prime}} X^{*}\right)^{-1}\right. \\
G(\Omega / B) \sim I W\left(S^{*}, T^{*}\right)
\end{gathered}
$$

The posterior means are given by $B^{*}=\left(X^{* \prime}, X^{*}\right)^{-1}\left(X^{*}, Y^{*}\right)$ and $S^{*}=\left(Y^{*}-X^{*}\right)$ $\tilde{B}\left(Y^{*}-X^{*} \tilde{B}\right)$, where $Y^{*}=\left[Y ; Y_{D, 1} ; Y_{D, 2}\right], X^{*}=\left[X ; X_{D, 1} ; X_{D, 2}\right]$ and $\tilde{B}$ is the draw of the VAR coefficients $B$ reshaped to be conformable with $X^{*} . T^{*}$ denotes the number of rows of $Y^{*}$.

To simulate the posterior distribution of $B$ and $\Omega$, Gibbs sampler is used with 20,000 iterations using the first 5,000 for the burn-in period.

\subsection{Model specification}

The Bayesian TVAR is applied to quarterly data from South Korea [2]. The data sample extends over the period between 1986Q2-2018Q3. The data consists of the variables: GDP, consumer price index (CPI), the logarithm of the real effective exchange rate (REER), credit 
AJEB

4,3

92

to the private non-financial sector (CPNF), the foreign capital inflows (INF), stock returns (R) and house price index. Foreign capital inflows are expressed as a percentage of GDP.

The Bayesian TVAR implements a recursive identification scheme to estimate the impulse response functions. Such an identification scheme creates a recursive contemporaneous ordering in which any variable does not contemporaneously depend on the variable ordered after. In this respect, the asset prices are ordered after capital inflows assuming that local assets can only affect capital inflows with lag. Such an assumption has also been used by Froot et al. (2001) and Kim et al. (2004). The rest of the variables i.e. GDP, CPI and CPNF are ordered before capital inflows. This ordering is motivated by the assumption that economic activities sluggishly respond to the economic conditions, while financial variables usually show an immediate response. The assumption was pioneered by Sims and Zha (2006) and has been commonly used in many studies.

The gross inflows of foreign capital are principally composed of three components, namely, FDI, foreign portfolio investments (FPI) and other foreign investments (OFI) [2]. The literature on international capital flows notes that the FDI and foreign portfolio flows have different dynamics, FDI is considered to be more resilient compared to the other components and contributes to the economic stability of the recipient country. The other components are often characterized by volatility and short-term trends. These differences are certainly worth serious consideration in the context of foreign capital impact on the recipient country. For this reason, the foreign capital inflows are taken by component to examine the nature of these flows and their relation to economic activities and asset prices in the second part of the empirical analysis.

\section{Analysis of the empirical results}

The descriptive statistics and the unit root testing procedures for the variables are reported in Tables 1 and 2, respectively. Except for the variable REER, all the other variables are normally distributed as indicated by the statistical significance of Jarque-Bera test statistics. The table of unit root tests shows that all the variables are stationary at level.

In addition, the Bai-Perron test of structural breaks is applied to the data of gross capital inflows and its components, the results of this test are reported in Table 3 . The break dates detected by the Bai-Perron test are perfectly concurrent with the events described in a previous section. The first break dates of foreign capital inflows simultaneously take place with the events of financial market liberalization in the early 1990s. The next break dates of foreign capital inflows are documented during the 1997 Asian currency crisis. The third

\begin{tabular}{lccccl}
\hline Variables & Mean & Median & Std. dev. & Jarque-Bera & Probability \\
\hline GDP & 2.223257 & 2.140356 & 1.821214 & 6.926743 & $0.031324^{*}$ \\
CPI & 0.923021 & 0.804566 & 0.861817 & 167.2815 & $0.000000^{* *}$ \\
REER & 1.995036 & 1.998050 & 0.045740 & 2.432340 & 0.296363 \\
CPNF & 2.705195 & 2.316207 & 2.002926 & 6.335489 & $0.042098^{*}$ \\
R & 1.062423 & 1.930627 & 11.78483 & 56.67622 & $0.000000^{* *}$ \\
HPI & 0.776934 & 0.482397 & 1.906881 & 41.42043 & $0.000000^{* *}$ \\
Gross inflows & 2.487937 & 2.850110 & 4.389193 & 366.3460 & $0.000000^{* *}$ \\
FDI & 0.874772 & 0.740759 & 0.611999 & 36.40260 & $0.000000^{* *}$ \\
FPI & 1.439168 & 1.313531 & 2.409055 & 14.48919 & $0.000714^{* *}$ \\
OFI & 0.173996 & 0.356178 & 3.522029 & 132.0295 & $0.000000^{* *}$
\end{tabular}

Table 1.

Descriptive statistics
Note: The asterisks *and **denote the statistical significance of Jarque-Bera statistics at levels of $5 \%$ and $1 \%$, respectively 


\begin{tabular}{|c|c|c|c|c|c|}
\hline \multirow[b]{2}{*}{ Variables } & \multicolumn{2}{|c|}{ Augmented Dickey-Fuller test } & \multicolumn{2}{|c|}{ Phillips-Perron test } & \multirow{2}{*}{$\begin{array}{l}\text { Impact of } \\
\text { foreign capital }\end{array}$} \\
\hline & Test statistic & $p$-value & Test statistic & $p$-value & \\
\hline GDP & -7.296644 & $0.0000 * * *$ & -7.844540 & $0.0000 * * *$ & \\
\hline CPI & -2.827928 & $0.0572^{*}$ & -9.458445 & $0.0000 * * *$ & \\
\hline REER & -3.449061 & $0.0110 * *$ & -2.867086 & $0.0521^{*}$ & \\
\hline CPNF & -2.975328 & $0.0399 * *$ & -7.014315 & $0.0000^{* * * *}$ & \\
\hline & -8.553440 & $0.0000^{* * * *}$ & -8.469924 & $0.0000^{* * * *}$ & \\
\hline HPI & -4.914269 & $0.0001 * * *$ & -4.947561 & $0.0001 * * *$ & \\
\hline Gross inflows & -6.726773 & $0.0000^{* * * *}$ & -6.829862 & $0.0000^{* * *}$ & \\
\hline & -2.944236 & $0.0432^{* *}$ & -8.099917 & $0.0000^{* * * *}$ & \\
\hline FPI & -8.458799 & $0.0000^{* * * *}$ & -8.515521 & $0.0000^{* * * * *}$ & \\
\hline OFI & -4.855876 & $0.0001^{* * * *}$ & -8.513536 & $0.0000^{* * * *}$ & $\begin{array}{l}\text { Table } 2 . \\
\text { Unit root tests at }\end{array}$ \\
\hline \multicolumn{5}{|c|}{ Note: The asterisks $* * *$ and $* * *$ denote statistical significance at levels of 10,5 and $1 \%$, respectively } & level with intercept \\
\hline Break dates & Gross inflows & FDI & FPI & OFI & \\
\hline Break date 1 & 1991Q2 & 1991Q4 & 1992Q4 & $1991 \mathrm{Q} 2$ & \\
\hline Break date 2 & 1998Q3 & 1997Q4 & 1997Q4 & 1998Q3 & \\
\hline Break date 3 & 2003Q2 & $2002 \mathrm{Q} 3$ & 2004Q2 & 2004Q1 & \\
\hline Break date 4 & 2008Q3 & 2007Q2 & 2009Q2 & 2008Q4 & \\
\hline Break date 5 & 2013Q2 & $2013 \mathrm{Q} 3$ & 2014Q1 & $2014 \mathrm{Q} 1$ & \\
\hline$F$-statistic & 9.646622 & 21.19465 & 6.795987 & 9.327519 & \\
\hline Scaled $F$-statistic & 9.646622 & 21.19465 & 6.795987 & 9.327519 & \\
\hline Weighted $F$-statistic & 21.16829 & 46.50898 & 14.91293 & 20.46806 & Break dates for gross \\
\hline Critical value & $3.91^{*}$ & $3.91^{*}$ & $3.91 *$ & $3.91^{*}$ & $\begin{aligned} \text { capital inflows and } \\
\text { foreign canital }\end{aligned}$ \\
\hline \multicolumn{5}{|c|}{ Note: The asterisk * denotes statistical significance at the $5 \%$ level } & components \\
\hline
\end{tabular}

break dates appear to be caused by the second wave of foreign capital inflows that took place in the early 2000s. The break dates also manifest the impact of the 2008 global financial crisis on foreign capital flows in South Korea.

\subsection{The impact of gross foreign capital inflows}

The identified regimes, shown in Figure 1, point to great instability of gross capital inflows. The most persistent episode of large inflows is noticed after the liberalization of the capital account in South Korea in the early 1990s. The second most lasting episode of large capital inflows starts from 2004 and ends with the 2008 global financial crisis. In contrast, the episodes of low capital inflows are mostly characterized by short duration, but they are relatively more frequent than the episodes of large flows. The responses to the shocks generated by the regimes of large and low foreign capital inflows are displayed in Figure 2. The size of the shock is set to one standard deviation increase in capital inflows. The absolute size of the shock is allowed to change across regimes. The contribution of shocks of large gross capital inflows to GDP is extremely weak and it is often statistically indifferent from zero. Contrarily, the shocks in the regime of low inflows have caused GDP to contract by almost $1 \%$ in the second quarter after the shock. CPI has responded analogously to shocks of large and low capital inflows. The shocks in both regimes have caused a 

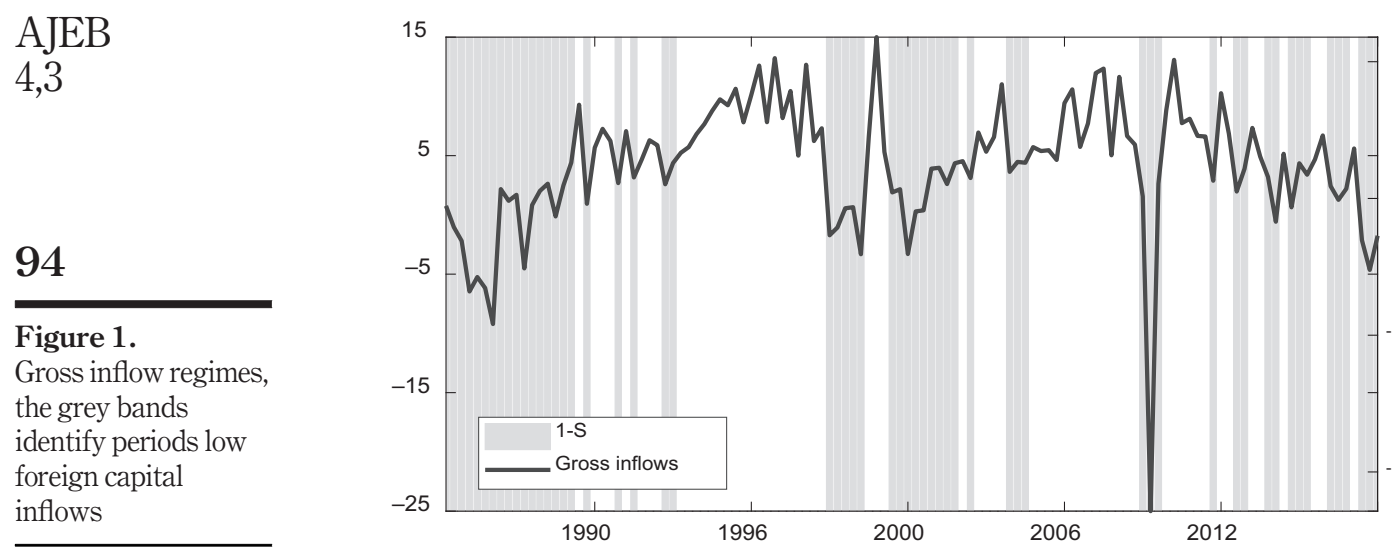

contemporaneous increase in the aggregate level of price by nearly $0.6 \%$. The REER appears to be the most sensitive variable to the changes in foreign capital inflows. As it is shown in Figure 2, the REER immediately depreciates after every shock to foreign capital inflows in both regimes. However, the shocks in the regime of low capital inflows have inflicted the sharpest impact causing the REER to depreciate by nearly $5 \%$. It is also interesting to note that the real exchange rate is not able to recover from these losses even in the long-term. As for credit growth, the shocks to foreign capital inflows of capital in both regimes are associated with a statistically significant increase in the credit supply to the private non-financial sector, albeit the credit supply associated with large inflows is slightly higher and more persistent. Contrary to common belief, stock returns and house prices are found to be negatively linked to shocks in gross foreign capital inflows. The stock returns immediately decrease by nearly $2 \%$ and $3 \%$ after every shock in the regimes of low and large capital inflows, respectively. House prices also tend to slightly fall right after the shocks to foreign capital inflows. Note that the largest decrease in house prices is noticed in the second quarter after the shock, with the impact of the shocks in low inflow regime being higher than the impact of the shocks in the regime of large inflows.

\subsection{The impact of foreign capital components}

This section analyzes the responses of economic activities and asset prices to the changes in the components of foreign capital inflows. The estimated regimes of large and low inflows for each component are displayed in Figure 3. As can be seen in this figure, the inflows of other investments are dominating the foreign investments in South Korea. The FDI has the smallest share of foreign investments and it seems to be as volatile as the other components. The share of FDI ranges between $0.5 \%$ and $3 \%$ of GDP over most of the sample period, while the share of OFIs has been comparatively higher during the episodes of large inflows. Note that the inflows of OFIs have unprecedently increased after the 1997 Asian currency crisis amounting to around $15 \%$ of GDP. It is also worth noting that the share of FDI has consistently been below 1\% of GDP prior to the Asian currency crisis in 1997 and started to break above that level only after the end of this crisis. The episodes of low foreign capital inflows are notably more frequent in the inflows of FDI and strikingly more persistent in the inflows of OFIs. The inflows of FPI, on the other hand, display significantly longer episodes of large inflows than the other components. 

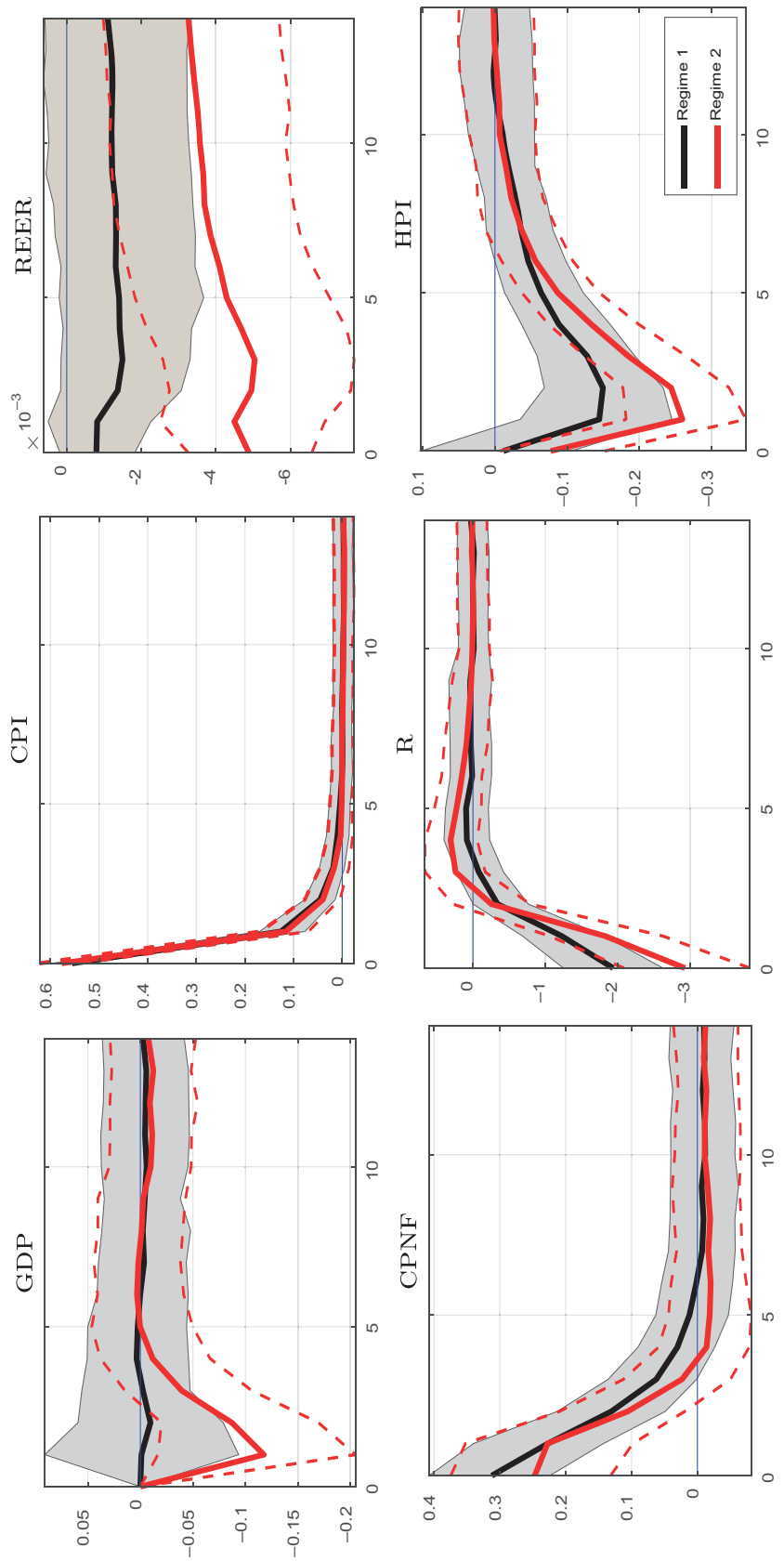

Impact of foreign capital shifts

$\stackrel{0}{ \pm}$

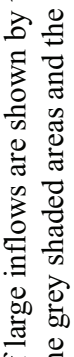

넝 寻

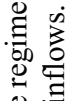

‥

$\Xi$ 으

ज范

运

욤

is.

突

की क

讷

.

w

要

क्षे :

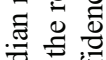

证

政

훌ㅇㅇㅇ

可

홍크

马

当赹

응

息总

$\ddot{\Xi}$

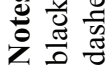

Figure 2.

Responses to shocks generated by regimes of gross inflows 
AJEB

4,3

96

Figure 3.

Regimes of foreign

capital components, the grey bands

identify periods of low foreign capital inflows
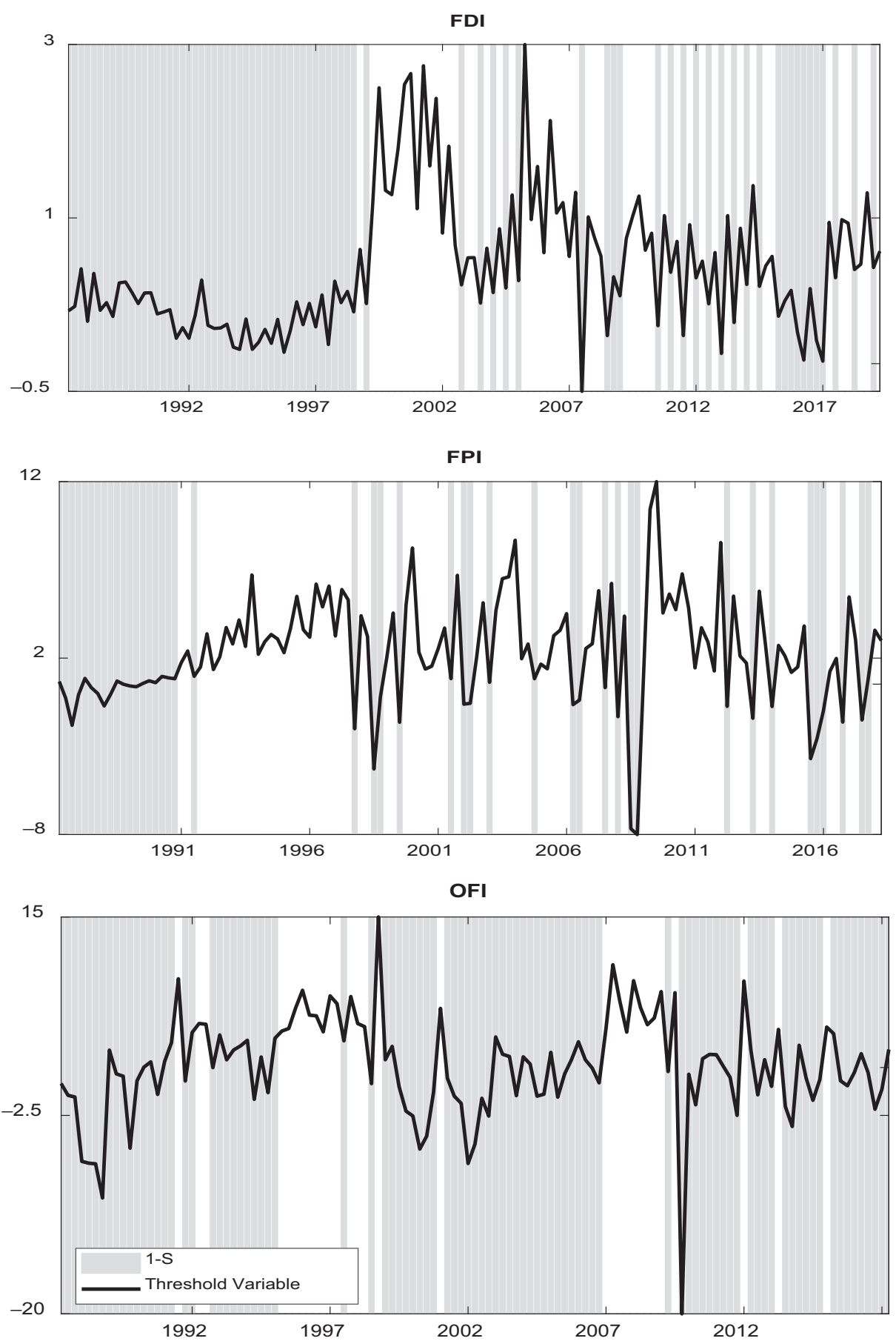
The responses of the variables to the shocks generated by the large and low inflows of FDI, FPI and the OFIs are shown in Figures 4-6, respectively. The estimated responses of credit and stock returns to the shocks in FDI, FPI and other investments are slightly different compared to the responses to shocks in gross foreign inflows. We also notice considerable changes in the responses of GDP, REER and house prices to the shocks generated by certain types of foreign capital. The aggregate level of prices, however, is showing the same responses to the shocks across all the regimes identified in foreign capital inflows at a gross level and the component level as well.

In further detail, GDP appears to be negatively associated with the shocks to FDI in both regimes. From Figure 4, we can observe that GDP is contracting by almost 1\% in response to shocks in the regime of large FDI inflows. The contraction of GDP is even deeper in response to the shocks in the regime of low FDI inflows. The shocks in both regimes have a highly persistent contractionary impact on GDP. Moreover, as shown in Figure 5, GDP is also contracting after the shocks to FPI in the regime of large inflows. The contraction caused by this shock is significantly smaller compared to the contraction caused by FDI. Another thing to note is that GDP tends to slightly grow after the shocks to FPI in the regime of low inflows, particularly, in the third quarter after the shock, but starts to contract again thereafter. On the contrary, the large inflows of OFIs appear to be the most contributing type of foreign inflows to GDP growth in South Korea, as displayed in Figure 6. The REER is found to be positively associated only with shocks to large inflows of FDI, while the other components of foreign capital inflows are causing significant depreciation of the exchange rate.

The responses of the credit growth displayed in Figures 4 and 6 suggest that the shocks to FDI and OFIs in both regimes are spurring more credit supply in South Korea. Note that the credit supply associated with the large inflows of FDI and OFIs is significantly larger. Furthermore, the shocks to FPI almost identically impact the credit supply across the two regimes as shown in Figure 5.

As for asset prices, recall that stock returns and house prices were found to be negatively affected by the shocks to gross inflows of foreign capital. Stock returns, similarly, have been constantly showing immediate decrease after every shock to the inflows of FDI, FPI and OFIs in both regimes. House prices, however, are showing a positive response to shocks of large and low FPI inflows as shown in Figure 5. This impact is particularly noticeable in the second quarter after the shock, meaning that the FPI inflows have significantly contributed to the appreciation of house prices in South Korea.

\section{Practical implications and limitations of the results}

While large capital inflows, in general, tend to support the long-term growth of income, it can also be associated with risks and financial vulnerabilities. Furthermore, the large inflows of foreign capital are often followed by reversals of capital flows, which slow down the economy and trigger a collapse in asset prices. In light of these ramifications, many studies such as Perrault (2002) and King (2001) explicitly stated that excessive capital flows were instrumental in sowing the seeds of the financial vulnerabilities to the Asian financial crisis. Therefore, it has been extremely challenging for policymakers to reap the benefits of foreign capital inflows without incurring large risks. South Korea, like many other emerging markets, has proactively responded to large capital inflows using different management tools, which include monetary policies, fiscal policies and foreign exchange interventions. Taking the composition of foreign capital into account could help to discern the sources of risk. In the case of South Korea, it turned out that components of foreign capital have a heterogeneous impact on the economy and asset prices. While large FDI inflows have been 
AJEB

4,3

98
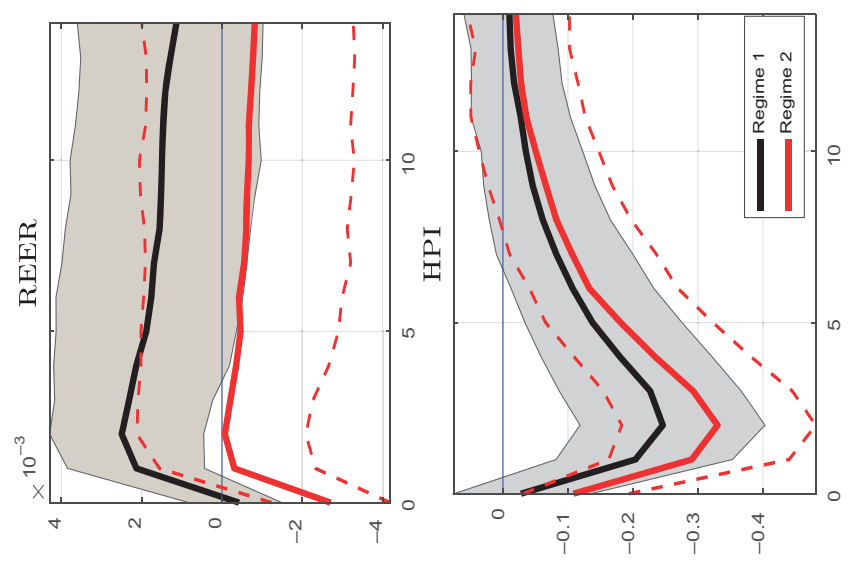

$\stackrel{0}{ \pm}$
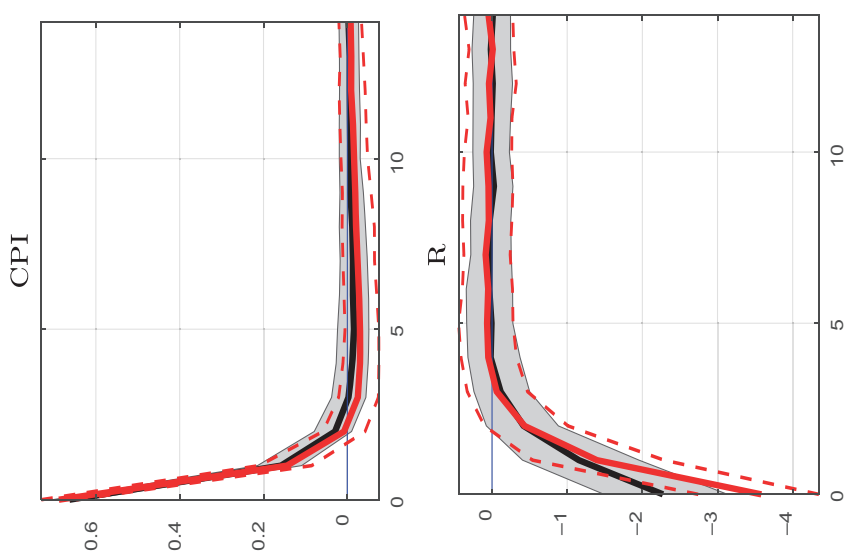

쵸표

氞

की

त

容造

$\exists$ స

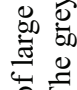

प्त 타

节施

导运

की

过

$\nsubseteq$

월

w.

है

क्ष

凷

is

雬

के क्षे
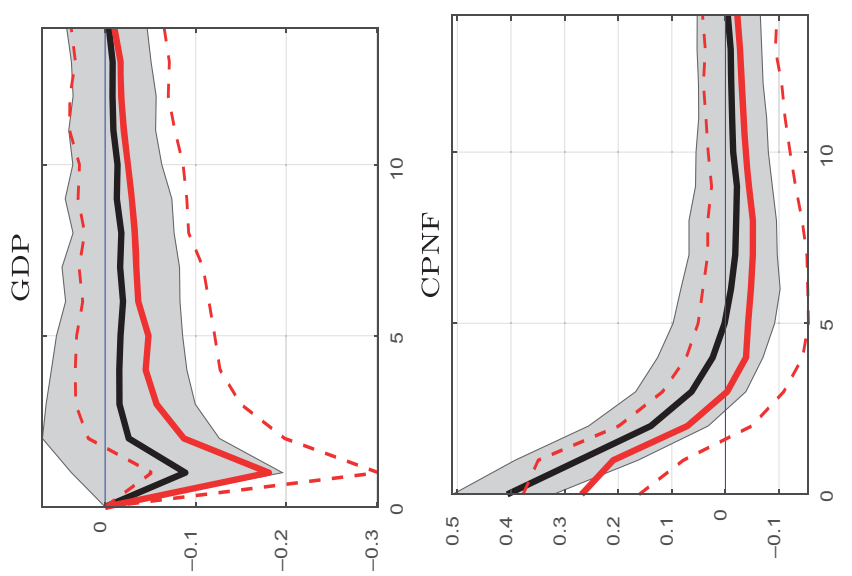

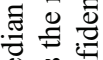

总

Ð

ए

远.

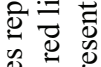

过蒂

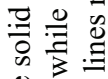

Е

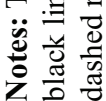

Figure 4 .
Responses to shocks generated by regimes of FDI inflows 

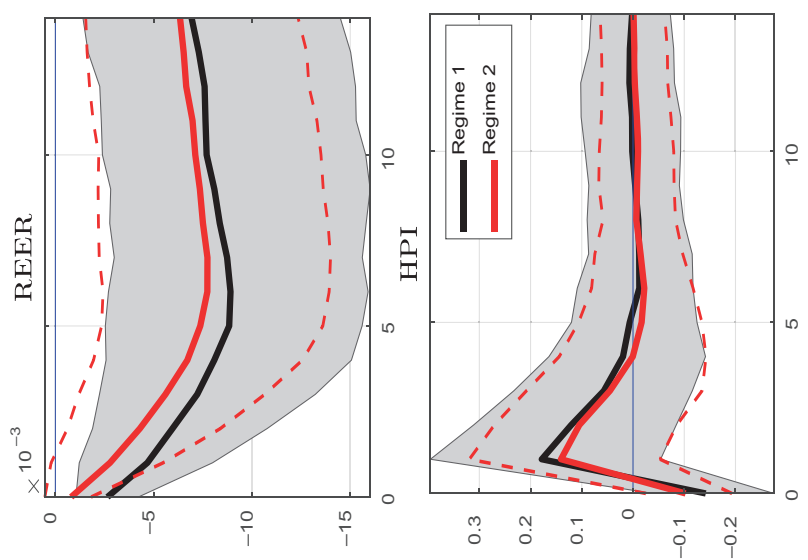

$\stackrel{5}{ \pm}$

Impact of
foreign capital
shifts
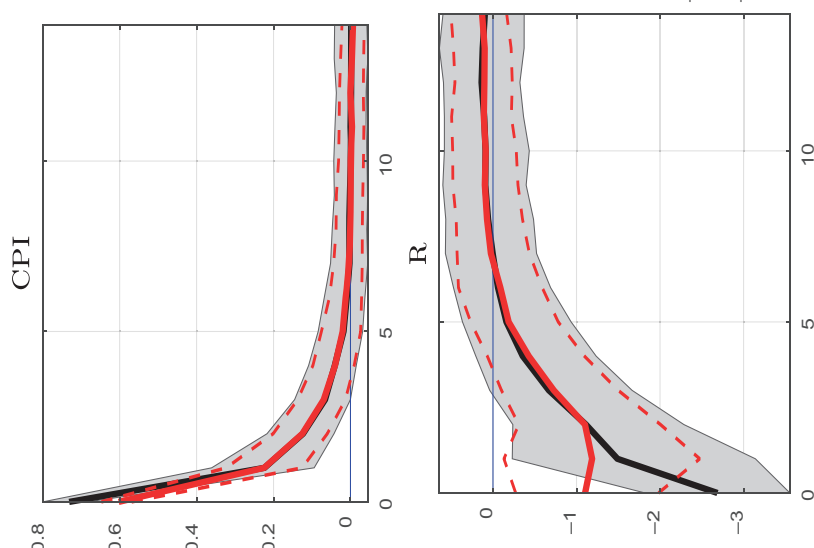

อ

离

品

늡

क्ष ठ্.

产

F

兽造

․ㅡ

in

궁

क

웡

o.

帘

के ज

동

F.

过

की

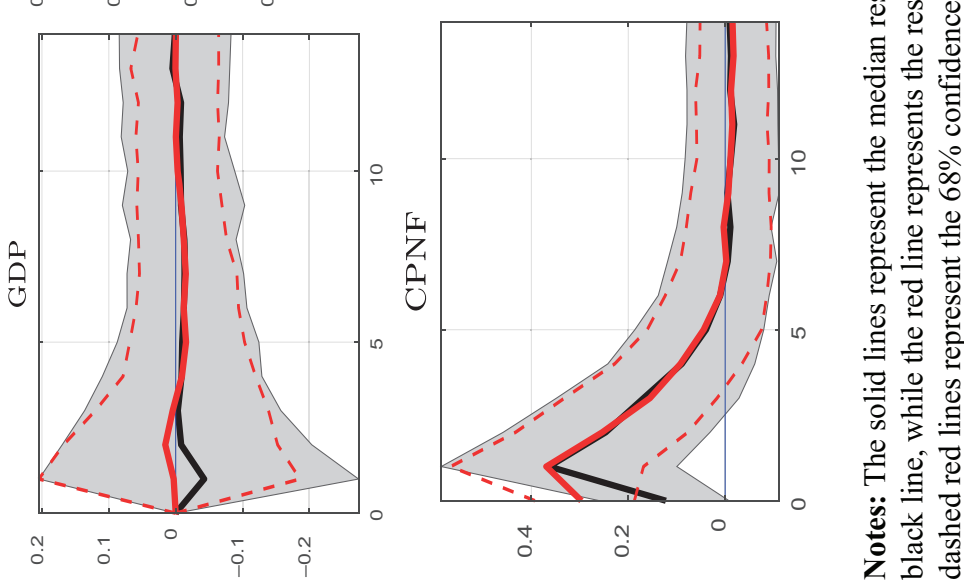

Figure 5.

Responses to shocks generated by regimes of FPI inflows 
AJEB

4,3

100

Figure 6.

Responses to shocks generated by regimes of other investment inflows
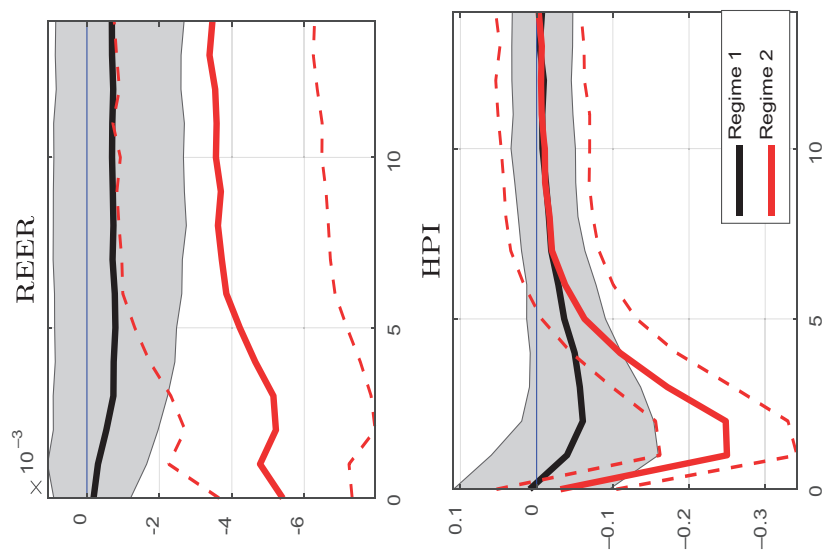

$\stackrel{9}{ \pm}$
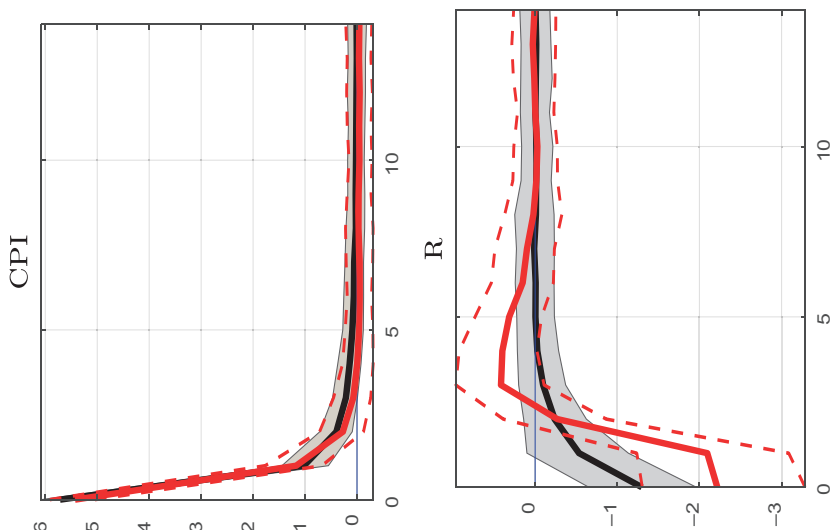

ลำ

垫

흔

定

题需

क्षे

츠 을

范

荡

Ф.

롱

ज我

응

क

․․․

욤

$\infty . \Xi$

d

ํํㅇ

के

욛

오

$\dot{s}$

范

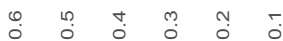
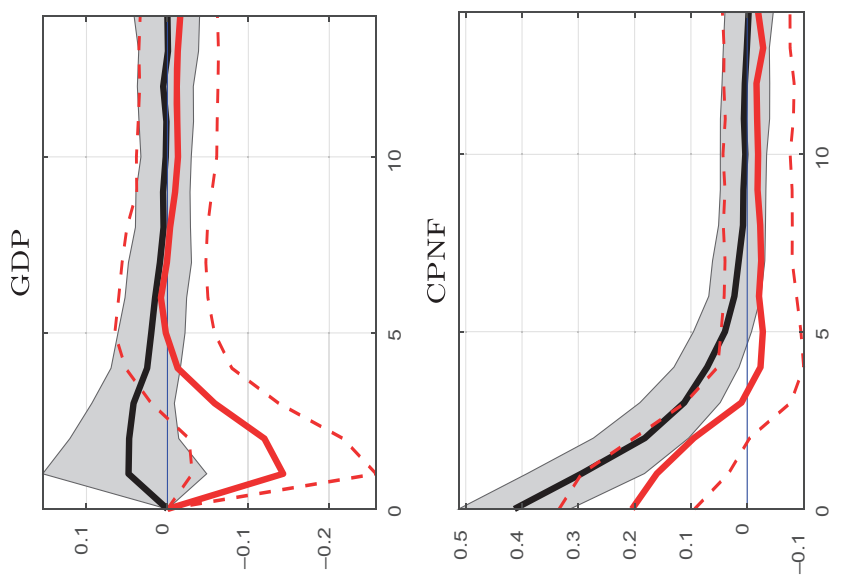

की क्षे

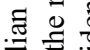

跑

व

$\stackrel{5}{ \pm}$

흥

D.

苛: 导

인

象造

믕 을

릴

$\because \Xi$

宛步 
inadequate to promote growth, large inflows of OFIs have indeed significantly contributed to GDP growth. This could be troublesome for the South Korean economy considering that OFIs are mostly channeled to the economy through bank credits. The large inflows of FDI also undesirably impact the South Korean economy by causing appreciation of the REER. For South Korea, as an export-oriented economy, it is important to curb sever appreciations of the exchange rate to keep export prices competitive. Besides, analyzing the effects of foreign capital inflows using a threshold-based method could be advantageous to capital management. For instance, the estimated thresholds for the past episodes of large inflows can help to distinctively break down the extent of risk caused by the irregular periodic changes in foreign capital, thus enables the policymakers to proportionately respond to the shocks generated by the surges and the reversals of foreign capital. This could be particularly relevant to the credit growth during the periods of large and low inflows of foreign capital. It is already demonstrated that large foreign capital inflows are associated with further expansion of credit growth. However, the credit supply is also found to be shrinking as foreign capital is decreasing, this could eventually lead to the slowdown of the economy in South Korea. To overcome this situation, the policymakers urged financial institutions to maintain countercyclical capital to compensate for the shortage of credit supply during periods of low foreign capital inflows. The advantage of such a policy is that it ensures the flow of the money into the economy during times of stress without exerting downside pressures on interest rates.

The policy implications of foreign capital inflows are of particular importance to all the emerging markets alike. However, our empirical analysis is limited to the case of South Korea due to various reasons. The experience with international capital inflows among emerging markets is heterogeneous. Therefore, it would be better to take each case of emerging markets individually. In addition, TVAR analysis requires a long data sample, which unfortunately is not available for many emerging markets.

\section{Conclusion}

This study implements a TVAR methodology to estimate the regime shifts of foreign capital inflows and its impact on economic growth, credit expansion and asset prices. The model is applied to South Korean data consisting of GDP, CPI, CPNF, gross foreign capital inflows, REER, stock returns and house prices. The model is also applied to the components of foreign capital to examine the nature of these flows and their relation to economic activities and asset prices. The empirical investigation is started by estimating the regimes of large and low inflows using a threshold autoregressive model. Then, structural impulse-response analysis is used to check whether the responses of the variables differ across the estimated regimes.

The results of the threshold autoregressive model point to great instability of gross foreign capital flows. The FDI is found to be the most unstable component of foreign investments and it is characterized by frequent changes from the regime of large to the regime of low inflows. The regime shifts are less frequent in the inflows of OFIs, but it has the most persistent episodes of low inflows. The inflows of FPI, on the other hand, display significantly longer episodes of large inflows than the other components.

The structural impulse-response analysis shows an extremely weak contribution of large foreign capital inflows to GDP growth in South Korea. The empirical analysis also reveals that the shocks generated by the low foreign capital inflows are causing GDP to contract by almost $1 \%$. The FDI is generally negatively associated with GDP growth, but the contraction of GDP is even deeper in response to the shocks generated by low inflows of FDI. The large inflows of OFIs, however, are found to be the most contributing type of foreign capital to GDP growth. Furthermore, the REER is found to be depreciating after 

well, the shocks generated by the low inflows of these foreign investments are associated with a much severe depreciation of REER. In contrast, the shocks generated by large FDI inflows have caused a significant appreciation of the REER. The credit supply is found to be significantly expanding when the foreign capital inflows are large, this expansion is particularly associated with the shocks generated by large inflows of gross foreign capital, FDI and OFIs. In regard to asset prices, the stock returns have been constantly showing immediate decrease after every shock to foreign capital inflows and its components. Similar responses have been shown by house prices to shocks generated by large and low inflows of gross foreign capital, FDI and OFIs. Contrarily, the shocks generated by large and low inflows of FPI has caused significant appreciation of house prices in South Korea.

To sum up, the main findings suggest that large inflows of gross foreign capital, FDI and FPI are ineffective to boost economic growth, but large inflows of OFIs significantly contribute to GDP. The decreases in the foreign capital inflows are associated with larger depreciation of REER. The large inflows of gross foreign capital, FDI and OFIs are associated with further expansion of credit supply to private non-financial sectors.

\section{Notes}

1. Generally, the criteria and definitions set in these studies to discriminate between episodes of capital inflows are somewhat subjective and considerably differ from one study to another in terms of the outcomes. See Crystallin et al. (2015) for a detailed review.

2. South Korea is an interesting case of emerging markets. It was one of the top five capitalreceiving countries among emerging markets as stated by Bosworth et al. (1999).

3. The other foreign capital investment flows are also referred to as bank flows in many studies. This component mostly consists of cross-border bank lending, see for example Broto et al. (2011).

\section{References}

Agosin, M.R. and Machado, R. (2005), "Foreign investment in developing countries: does it crowd in domestic investment?", Oxford Development Studies, Vol. 33 No. 2, pp. 149-162.

Aizenman, J., Jinjarak, Y. and Park, D. (2013), "Capital flows and economic growth in the era of financial integration and crisis, 1990-2010", Open Economies Review, Vol. 24 No. 3, pp. 371-396.

Alessandri, P. and Mumtaz, H. (2017), "Financial condition and density forecasts for US output and inflation", Review of Economic Dynamics, Vol. 24, pp. 66-78.

Aliber, R.Z. and Kindleberger, C.P. (2015), Maniacs, Panics and Crashes: A History of the Financial Crises, Palgrave Macmillan. London.

Banbura, M., Giannone, D. and Reichlin, L. (2010), "Large Bayesian vector auto regression”, Journal of Applied Econometrics, Vol. 25 No. 1, pp. 71-92.

Baskaya, Y.S., Di Giovanni, J., Kalemli-Özcan, S., Peydró, J.L. and Ulu, M.F. (2017), “Capital flows and international credit channel”, Journal of International Economics, Vol. 108 No. 1, pp. S15-S22.

Beckmann, J. and Czudaj, R. (2017), "Capital flows and GDP in emerging economies and the role of global spillovers", Journal of Economic Behavior and Organization, Vol. 142 No. C, pp. 140-163.

Bosworth, B.P., Collins, S.M. and Reinhart, C.M. (1999), "Capital flows to developing economies: Implications for saving and investment", Brookings Papers on Economic Activity, Vol. 1999 No. 1, pp. 143-180.

Brana, S., Djigbenou, M.L. and Prat, S. (2012), "Global excess liquidity and asset prices in emerging countries: a PVAR approach”, Emerging Markets Review, Vol. 13 No. 3, pp. 256-276. 
Broto, C., Diaz Cassou, J. and Erce, A. (2011), "Measuring and explaining the volatility of capital inflows to emerging countries", Journal of Banking and Finance, Vol. 35 No. 8, pp. 1941-1953.

Caballero, R.J. and Krishnamurthy, A. (2006), "Bubbles and capital flow volatility: causes and risk management”, Journal of Monetary Economics, Vol. 53 No. 1, pp. 35-53.

Calderon, C. and Serven, L. (2013), "Macroprudential policies over the cycle in Latin America", in Emerging Issues in Financial Development: Lessons from Latin America, Washington, DC, World Bank, pp. 395-486.

Calvo, G.A. (1998), "Capital flows and capital market crises: the simple economics of sudden stops", Journal of Applied Economics, Vol. 1 No. 1, pp. 33-54.

Carbonell, J.B. and Werner, R.A. (2018), "Does foreign direct investment generate economic growth? A new empirical approach”, Economic Geography, Vol. 94 No. 4, pp. 425-456.

Cardarelli, R., Elekdag, S. and Kose, A.M. (2010), "Capital inflows: macroeconomic implications and policy responses”, Economic Systems, Vol. 34 No. 4, pp. 333-356.

Carkoviç, M. and Levine, R. (2005), "Does foreign direct investment accelerate economic growth?", in Does Foreign Direct Investment Promote Development?, Washington, DC, Institute for International Economics, pp. 195-220.

Choong, C.-K., Baharumshah, A.Z., Yusop, Z. and Habibullah, M.S. (2010), "The private capital flows, stock market and economic growth in developed and developing countries: a comparative analysis", Japan and the World Economy, Vol. 22 No. 2, pp. 107-117.

Crystallin, M., Efremidze, L., Kim, S., Nugroho, W., Sula, O. and Willett, T. (2015), "How common are capital flows surges? How they are measured matters a lot", Open Economies Review, Vol. 26 No. 4, pp. 663-682.

DeLong, B.J. (2004), "Should we still support untrammeled international capital mobility? Or are capital controls less evil than we once believed?", The Economists' Voice, Vol. 1 No. 1, pp. 1-7.

Forbes, K.J. and Warnock, F.E. (2012), "Capital flow waves: surges, stops, flight and retrenchment", Journal of International Economics, Vol. 88 No. 2, pp. 235-251.

Froot, K.A., O'Connell, P.G.J. and Seasholes, M.S. (2001), "The portfolio flows of international investors", Journal of Financial Economics, Vol. 59 No. 2, pp. 151-193.

Ghosh, A., Qureshi, S.M., Kim, J.I. and Zalduendo, J. (2014), Journal of International Economics, Vol. 92 No. 2, pp. 266-285.

Henry, P.B. (2007), "Capital account liberalization: theory, evidence, and speculation”, Journal of Economic Literature, Vol. 45 No. 4, pp. 887-935.

Hernandez, L. and Landerretche, O. (1999), "Capital inflows, credit booms, and macroeconomic vulnerability: the cross-country experience", Money Affairs, Vol. 12 No. 1, pp. 1-69.

Igan, D. and Tan, Z. (2017), "Capital inflows, credit growth, and financial systems", Emerging Markets Finance and Trade, Vol. 53 No. 12, pp. 2649-2671.

Jansen, J.W. (2003), "What do capital inflows do? Dissecting the transmission mechanism for Thailand, 1980-1996”, Journal of Macroeconomics, Vol. 25 No. 4, pp. 457-480.

Javorcik, B.S. (2004), "Does foreign direct investment increase the productivity of domestic firms? In search of spillovers through backward linkages", American Economic Review, Vol. 94 No. 3, pp. 605-627.

Kim, S. and Yang, Y.D. (2009), "Do capital inflows matter to asset prices? The case of Korea", Asian Economic Journal, Vol. 23 No. 3, pp. 323-348.

Kim, S. and Yang, D.Y. (2011), "The impact of capital inflows on asset prices in emerging Asian economies: is too much money chasing too little good?", Open Economies Review, Vol. 22 No. 2 , pp. 293-315.

Kim, S., Kim, S.H. and Wang, Y. (2004), "Macroeconomic effects of capital account liberalization: the case of Korea", Review of Development Economics, Vol. 8 No. 4, pp. 624-639. 
AJEB

4,3

104

King, M.R. (2001), “Who triggered the Asian crisis?", Review of International Political Economy, Vol. 8 No. 3, pp. 438-466.

Kose, A.M., Prasad, E.S. and Terrones, M.E. (2009), "Does the openness to international financial flows raise productivity?", Journal of International Money and Finance, Vol. 28 No. 4, pp. 554-580.

Li, X. and Liu, X. (2005), "Foreign direct investment and economic growth”, World Development, Vol. 33 No. 3, pp. 393-407.

Magud, N.M., Reinhart, C.M. and Vesperoni, E.R. (2014), "Capital inflows, exchange rate flexibility and credit booms", Review of Development Economics, Vol. 18 No. 3, pp. 415-430.

Perrault, J.F. (2002), "Private capital flows to emerging market economies", Bank of Canada Review, Spring, pp. 33-43.

Reinhart, C.M. and Reinhart, V.R. (2009), "Capital flows bonanzas: an encompassing view of the past and present", in NBER International Seminar on Macroeconomics, MA: University of Chicago Press, pp. 9-62.

Rodrik, D. and Subramanian, A. (2009), "Why did financial globalization disappoint?", IMF Staff Papers, Vol. 56 No. 1, pp. 112-138.

Sachs, J., Tornell, A. and Velasco, A. (1996), "Financial crises in emerging markets: the lessons from 1995”, Brookings Papers on Economic Activity, Vol. 1996 No. 1, pp. 147-199.

Sa, S. (2006), "Capital flows and credit booms in emerging market economies", Financial Stability Review, Vol. 9, pp. 49-66.

Sims, C.A. and Zha, T. (2006), "Does monetary policy generate recessions?”, Macroeconomic Dynamics, Vol. 10 No. 2, pp. 231-272.

Ventura, J. (2012), "Bubbles and capital flows”, Journal of Economic Theory, Vol. 147 No. 2, pp. 738-758.

\section{Corresponding author}

Boubekeur Baba can be contacted at: bb359@anadolu.edu.tr

For instructions on how to order reprints of this article, please visit our website: 